\title{
Kahramanmaraş İli Badem Ağaçlarında Bakla Zınnı (Epicometis Hirta (Poda, 1761)) (Coleoptera: Scarabaeidae)'nın Farklı Tuzaklarla Yakalanması Üzerine Araştırma
}

\author{
Ö. Murat ARSLAN ${ }^{1}$, M. Murat ASLAN ${ }^{1 *}$ \\ ${ }^{1}$ KSÜ, Ziraat Fakültesi, Bitki Koruma Bölümü, Avşar Kampüsü, Kahramanmaraş
}

Geliş (Received): 05.11.2015

Kabul (Accepted): 16.11.2015

\begin{abstract}
Özet: Kahramanmaraş ili Dulkadiroğlu ilçesine bağlı Karacasu Yöresi sınırları içerisinde bulunan 172 dekar Ferraduel çeşidi badem (Prunus amygdalus Batsch) bahçesinde Şubat 2015 ile Haziran 2015 tarihleri arasında farklı tuzak tipleri ile Epicometis hirta (Poda, 1761) 'nın yakalanma etkinliğinin araştırılması üzerine yapılan çalışmayla, farklı tipteki tuzakların etkisi ortaya konulmuştur. Çalışmada 4 tuzak tipi kullanılmıştır. Toplam 35 tuzakla yapılan 12 sayım sonucunda 8.762 adet Epicometis hirta (Poda, 1761) rastlanmıştır. Zararlının en fazla huni tipi tuzaklara yöneldiği tespit edilmiştir. Ayrıca zararlının Mart ayının ilk haftasında günlük hava sıcaklığının ortalama $9-10{ }^{\circ} \mathrm{C}$ olduğu zamanlarda çıkış yapmaya başladığı, Mart ayının sonu ile Nisan ayı ortasına kadar olan süreçte popülasyonunun en yoğun olduğu tespit edilmiştir. Bu bölge için zararlının, bitkinin fenolojik dönemi olarak çiçek döneminde zarar yaptığı belirlenmiştir.
\end{abstract}

Anahtar Kelimeler: Epicometis hirta, badem, farklı tuzaklar, Kahramanmaraş

\section{The Activity of Catching Epicometis Hirta (Poda, 1761) (Coleoptera: Scarabaeidae) with Different Trap} Types on Almond Trees in Kahramanmaraş Province

Abstract: This study was conducted to observe the affect of different trap types on catching activities of Epicometis hirta (Poda, 1761)) in a 172 Ferraduel variety almond tree (Prunus amygdalus Batsch) orchyard between February 2015 and June 2015 in Karacasu, Dulkadiroğlu, Kahramanmaraş. Four different types of trap were used in the study. Total of 8.762 Epicometis hirta (Poda, 1761)) were catched at the end of 12 countings in 35 traps totally. It is observed that insect pests were mostly tend to prefer the cone shape traps.. Besides, it is also observed that insect pests appear in the first week of March when the daily temperature was about $9-10^{\circ} \mathrm{C}$ or above at the end of March and the middle of April. During this times in this region, the population was on peek and concequentely they damage plant in florescence of phenological period.

Key Words: Epicometis hirta, almond, varies trap types, Kahramanmaras

\section{GÍRIŞ}

Epicometis hirta (Poda) (Coleoptera: Scarabaeidae) kışı larva ve ergin dönemde toprakta geçirir. E. hirta larvalarının genellikle bireysel yaşadığını ve ayrışmakta olan odun, ölü yaprak ve tek yıllık bitki kökleri ile beslendiğini belirtmiştir (Demir, 2005). İlkbaharda, meyve ağaçlarının ve diğer bitkilerin çiçek açma zamanında çıkan erginler, daha çok çiçekle beslenir. Yumurtalarını humusça zengin topraklara bırakır, 1-2 hafta sonra yumurtadan çıkan larvalar yabancı otların kökleri ile beslenir. Daha sonra pupa olur. İlkbahar sonunda ergin popülasyonu en yüksek duruma gelir. Bazı bölgelerde Temmuz ortasına kadar uçuştukları görülür (Hurpin 1962; Özbek ve ark., 1998; Özbek, 2008).

Bakla zınnı ilkbaharda çıkar ve meyve ağaçları, çilek, gül, buğdaygiller gibi bitkilerin çiçeklerinde beslenerek, erkek ve dişi organlarında zarar yapar. Uçma kapasiteleri yüksek olduğu için değişik bitkilere geçer ve zararlarını devam ettirir. Bunun sonucu olarak zarar görmüş çiçekler meyve bağlayamaz. Bulgaristan'da yaptıkları bir çalışmada, E. hirta'nın genç kiraz ağaçlarının çiçekleriyle beslendiğini ve \% 70'e kadar zarar yaptıklarını bildirmiştir (Kutinkova ve Andreev, 2004).

Badem ilk olarak İran, Türkiye, Suriye ve Filistin de yetiştirilmiş, buralardan da Yunanistan, Kuzey Afrika, İtalya ve İspanya'ya, sonraki dönemlerde ise Kuzey Amerika'ya götürülmüştür ve bilhassa Kaliforniya'da 1940 yıllarından sonra badem yetiştiriciliğinde önemli ilerlemeler kaydedilmiştir. Badem kuzey yarımkürede 30-44 enlem dereceleri arasında, güney yarımkürede ise 20-40 enlem dereceleri arasinda ve 600-1000 metre yüksekliklerde üretimi rahatlıkla yapılabilmektedir (Atlı ve ark., 2011).

Rosaceae familyasının Prunus cinsine bağlı badem (P. amygdalus Batsch.) Akdeniz havzasının sicak ve kurak bölgeleri ile batı Asya'nın 1lıman iklime sahip kısımlarında yabani veya yarı yabani olarak yetişmektedir. Badem kültürü çok eski yıllar öncesinde ilk olarak Anadolu, İran, Suriye ve Filistin'de başlamış, buradan Akdeniz havzasına yerleşmiştir (Rugini and Monastra, 2003; Özçağıran ve ark. 2005).

Son yıllarda, özellikle GAP (Güneydoğu Anadolu Bölgesi) bölgesinde badem fidanlıkların arttığı gözlenmektedir. Sicak iklim meyvesi olan badem, 
meyvelerinin olgunlaşması için yüksek sıcaklıklara gereksinim duymasından dolayı Anadolu'nun çok yüksek yaylaları ve Karadeniz bölgesinin serin ve nem oranı yüksek kesimleri hariç Anadolu'nun hemen hemen diğer bütün bölgelerinde kolaylıkla yetiştirilebilmektedir. Ülkemizde modern yetiştiricilik yapılan kapama badem fidanlıkları son yıllarda hızlı bir şekilde oluşturulmaktadır. Geç çiçek açan tiplerin ve çeşitlerin üretime kazandırılma oranı gittikçe artmaktadır. Badem daha çok meyvesi için önem kazanmıştır. Botanik yönden sert çekirdekli (drupa tipte) bir meyve yapısına sahip olmasına rağmen, badem olgunluk döneminde mezokarpın kuruyarak derimsi bir hal almasiyla, sert kabuklu meyve olarak değerlendirilmektedir (Soylu, 2003).

Ülkemiz toplam meyve üretiminin \% 6,4'ünü sert kabuklu meyveler oluşturmaktadır. Sert kabuklu meyve türleri arasında ağaç sayısının \% 1,2'sini ve üretim miktarının \% 4,3'ünü ise badem oluşturmaktadır. Dünya badem üretimi, miktar olarak büyük rakamlara ulaşmamakla birlikte, değer bakımından dünya ticaretinde önemli sayılacak derecede rol oynamaktadır. Devletin sertifikalı fidana destek vermesi ile kapama bahçeler tesis edilerek yapılan üretim artmıştır (Atlı ve ark., 2011).

Bahadıroğlu ve ark., (2007), 2002 - 2004 yıllarında Kahramanmaraş ili Ahır Dağı ve çevresinde yaptıkları çalışmada Bakla zınnı (Epicometis hirta)'nın 700-1400 m yükseltilerinde yoğun popülasyona ulaştığını bildirmişlerdir. Gezer (2015), 2013 ve 2014 y1lında Çanakkale ili Merkez, Lapseki, Ezine ve Bayramiç ilçelerinde 11 farklı şeftali, kiraz, kayısı ve elma bahçelerinde ağaçların çiçek kısımlarında zarar meydana getiren Epicometis (=Tropinota) hirta (Coleptera: Scarabaeidae)'nın en fazla hangi tuzaklarla yakalanabileceğini tespit etmek amacıyla yapmış olduğu çalışmada en fazla erginin mavi leğen + cezbedici tuzaklarda yakalandığını bildirmiştir.

Kahramanmaraş ilinde badem yetiştiriciliği her yıl yeni bahçelerin kurulmasıyla birlikte artmıştır. Badem zararlıları arasinda son y1llarda badem meyvesinde Bakla zınnı (Epicometis hirta) önemli ekonomik kayıplara neden olduğu tespit edilmiştir. Bu nedenle bu çalışmada yapılan uygulamalar ile kullanılan tuzak tiplerinin Baklazınnının yakalamadaki etkinliği araştırılmıştır. Yapılan uygulamalar ile Kahramanmaraş ilinde bulunan badem bahçelerinde verim ve kalite artışının sağlanmasına, birim alandan alınan net gelirin artmasına, üreticilerin daha fazla kâr etmesine yardımcı olacak veriler elde edilmeye çalışılmıştır.

\section{MATERYAL ve METOT}

Çalışmanın ana materyalini Kahramanmaraş ili Dulkadiroğlu ilçesine bağlı Karacasu Yöresinde bulunan 172 dekar badem bahçesi ve bu bahçede bulunan Bakla zınnı (Epicometis hirta) oluşturmuştur. Ayrıca çalışmada eşeysel çekici feromon kapsül, huni tipi tuzak, leğen tipi tuzak, plaka tipi yapışkan tuzak ve kova tipi tuzak (Karasinek tuzağı için kullanılan tuzak tipidir) kullanılmıştır. Kova tipi tuzağı bu zararlıya uygun hale getirmek için ağız delikleri zararlının girebileceği büyüklüğe ve kırmızı olan kapak kısmı mavi sprey boya ile mavi renge dönüştürülmüştür. Plaka tipi yapışkan tuzak da Epicometis hirta'nın mavi renge duyarlılığından dolayı maviye boyanmıştır ve tuzaklar araziye 25 Şubat 2015 tarihinde yerleştirilmiştir. Zemin üzerine konulan huni tipi tuzak ile leğen tipi tuzakta; sıra üzeri $8 \mathrm{~m}$, sıra arası ise $10 \mathrm{~m}$ olacak şekilde yerleştirilmiştir. Kova tipi tuzak ile plaka tipi tuzak ağaçların güneye bakan kısımlarına yerleştirilmiştir.

Tuzağa feromon kapsül asma işlemi esnasında feromon kapsüller askı tellerine asılıp sabitlenmiştir. Huni tipi tuzaklarda huniler, içi $1 \backslash 3$ oranında su ile doldurulan 10 litrelik pet bidonlar üzerine yerleştirilip, koli bandı yardımı ile (olumsuz hava koşullarında devrilmeyi engellemek amacı ile) pet bidonların ağız kısmı ile hunilerin birleştiği kısımdan yapıştırılarak sabitlenmiştir. Her tuzak tipi kendi alanında ve diğer tuzakların etki alanına girmeyecek şekilde $400 \mathrm{~m}^{2}$ alanı kapsayacak şekilde yerleştirilmiştir. Sayımlar hava koşulları da göz önünde tutularak 5 günde bir yapılmış, eşeysel çekici feromon kapsüller her sayım sonrası yenilenmiştir. Ayrıca eşeysel çekici feromon kapsülün etkisini araştırmak amacıyla kapsül olmayan kontrol tuzaklar oluşturularak sayımlar yapılmıştır. Bu işlem bütün tuzak tipleri için aynı şekilde yapıllmıştır.

Yabanc1 ot yoğunluğunun fazla olduğu dönemlerde boyları uzayan yabancı otların tuzak etrafinı sarmalamasını engellemek amacı ile orak yardımı ile tuzakların çevresi temizlenmiştir.

\section{BULGULAR VE TARTIŞMA}

Kahramanmaraş ili Dulkadiroğlu ilçesine bağlı Karacasu Yöresi sınırları içerisinde bulunan badem bahçesinde yapılan çalışma sonucunda elde edilen Epicometis hirta'ya ait veriler 4 farklı tuzak tipine göre (Çizelge 1 ve Şekil 1)'de verilmiştir. 
Çizelge 1. Epicometis hirta sayılarının tuzak tiplerine göre yakalanma sayıları

\begin{tabular}{|c|c|c|c|c|}
\hline \multirow{2}{*}{ Sayımın Yapıldı̆̆ı Tarih } & \multicolumn{4}{|c|}{ Tuzak tipleri } \\
\cline { 2 - 5 } & Huni tipi & Leğen tipi & Kova tipi & Plaka tipi \\
\hline 01.03 .2015 & 1 & 1 & 0 & 0 \\
\hline 06.03 .2015 & 42 & 28 & 5 & 0 \\
\hline 11.03 .2015 & 218 & 44 & 20 & 0 \\
\hline 15.03 .2015 & 96 & 48 & 9 & 0 \\
\hline 27.03 .2015 & 1334 & 428 & 76 & 0 \\
\hline 08.04 .2015 & 1685 & 703 & 55 & 0 \\
\hline 17.04 .2015 & 1497 & 799 & 114 & 0 \\
\hline 22.04 .2015 & 419 & 325 & 36 & 0 \\
\hline 28.04 .2015 & 327 & 318 & 20 & 0 \\
\hline 03.05 .2015 & 53 & 36 & 3 & 0 \\
\hline 09.05 .2015 & 11 & 7 & 0 & 0 \\
\hline 14.05 .2015 & 3 & 1 & 0 & $\mathbf{0}$ \\
\hline TOPLAM & $\mathbf{5 6 8 6}$ & $\mathbf{2 7 3 8}$ & $\mathbf{3 3 8}$ & \\
\hline
\end{tabular}

NOT: Sayımlar 5 gün üzerinden yapılmıştır. Hava koşulları nedeni ile 4. sayım 3 gün üzerinden, 6 . sayım ise 4 gün üzerinden yapılmıştır. Ayrıca yağışı ve kapalı havada zararlının aktif olmaması nedeni ile yağışlı geçen ve havanın kapalı olduğu tarihlerde sayım yapılmamıştır.

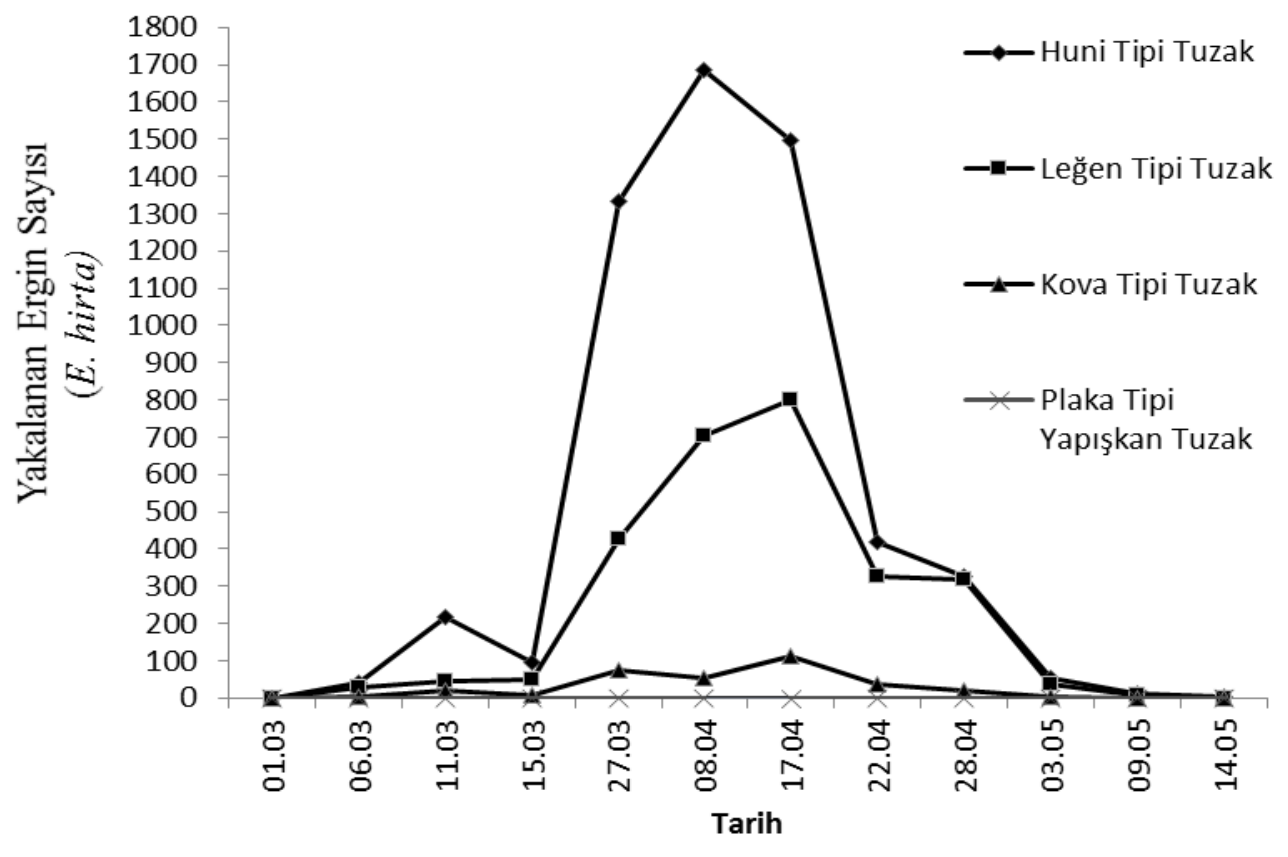

Şekil 1. 2015 yılı Epicometis hirta erginlerinin tuzak tiplerine göre yakalanma sayıları

Yukarıda verilen Çizelge 1 ve Şekil 1'deki verilere göre yakalanan Epicometis hirta erğin sayısının Mart ayı sonundan başlayarak Nisan ayı ortasına kadar geçen sürede olduğu görülmektedir. Bunun da sıcaklık, nem ve bitkinin fenolojik dönemi (çiçek dönemi) ile bağlantılı olduğu belirlenmiştir. Zararlı için bu süreçteki sıcaklık koşulları zararlının en aktif olduğu sıcaklık aralığı olarak söylenilebilir. Çiçek döneminin bitmesi ile zararlının popülasyonu hızlı bir şekilde azalma göstermiştir. Son 3 sayım çiçek döneminin bittiği dönemleri kapsamaktadır. 2015 yılı Ocak ayından başlayarak 23 Haziran tarihine kadar olan sürede günlük maksimum sıcaklık ve minimum sıcaklık verileri ile beraber günlük ortalama nem değerleri verileri (Şekil 3 ve Şekil 4)'te verilmiştir.

Yine incelendiğinde tuzaklara yakalan Epicometis hirta sayısının en fazla huni tipi tuzakta ve onu sırasıyla legen ve kova tipi tuzakların takip ettiği saptanmıştır (Çizelge 1 ve Şekil 1). Plaka tipi yapışkan tuzağa zararlının yönelmemesi, tuzakta bulunan yapışkan maddenin kokusundan kaynaklandığını ve bu kokunun repellent etkisi yaptığı kanısına varılmıştır. 


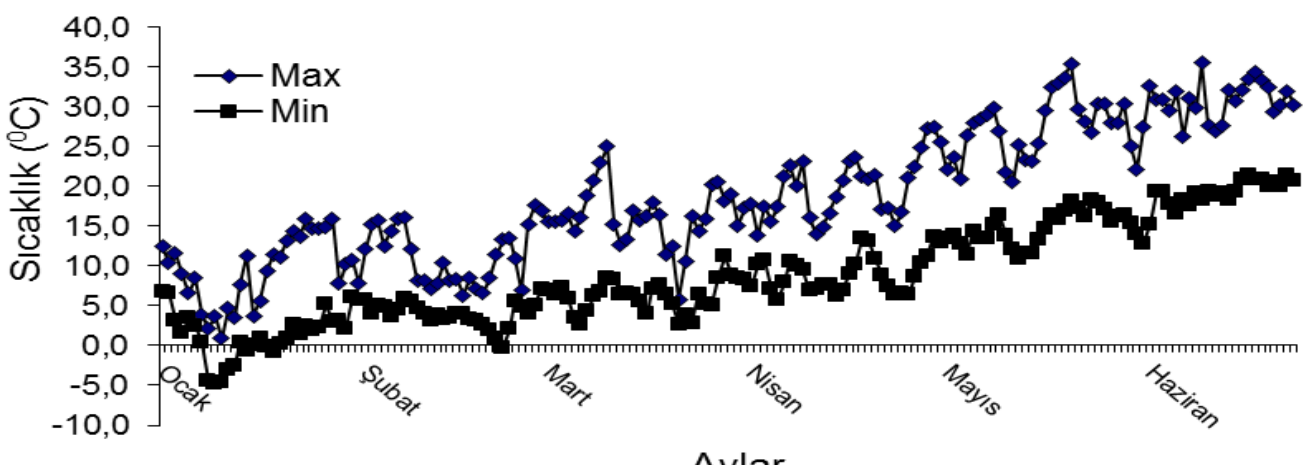

Aylar

Şekil 3. 2015 yılı Ocak - Haziran ayları arasındaki maksimum ve minimum sıcaklık değerleri

Sicaklığın popülasyon yoğunluğu üzerine etkisi oldukça önem arz etmektedir. Zararlının, günlük ortalama sıcaklık değeri olarak $9-25{ }^{\circ} \mathrm{C}$ aralığındaki sicaklıklarda aktif olduğu tespit edilmiştir. Bitki çiçek döneminde iken popülasyon yoğunluğunun en fazla olduğu günlük ortalama sıcaklık; $13-15 \quad{ }^{\circ} \mathrm{C}$ aralığındadır. Gece gündüz sıcaklık farkınında popülasyon yoğunluğuna etki ettiği düşünülmektedir.

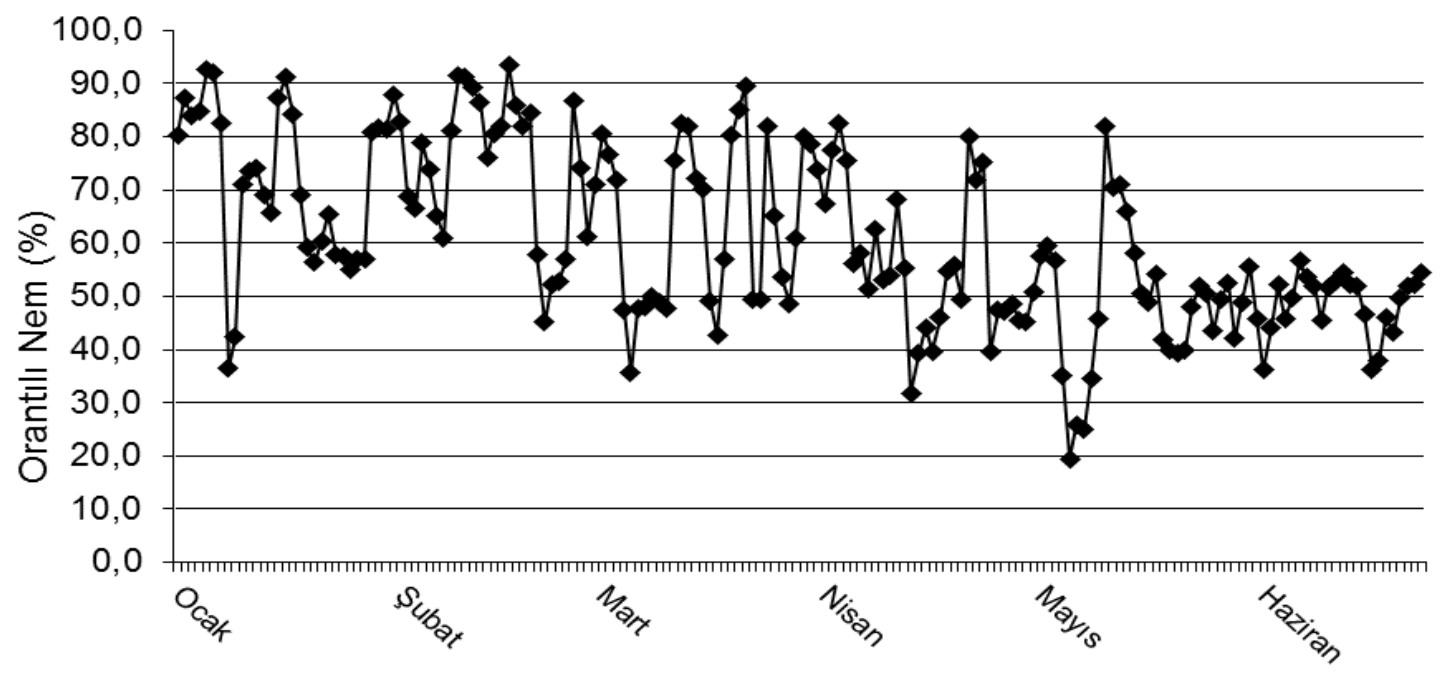

Aylar

Şekil 4. 2015 yılı Ocak - Haziran ayları arasındaki günlük ortalama nem değerleri

Zararlının, günlük ortalama nem değeri olarak \% 30-75 aralığındaki nem değerlerinde aktif olduğu tespit edilmiştir. Bitki çiçek döneminde iken popülasyon yoğunluğunun en fazla olduğu günlük ortalama nem aralığ $\%$ 40-60 olarak tespit edilmiştir.

İlk ergin çıkışı 1 Mart 2015 tarihinde sıcaklığın ortalama $9-10{ }^{\circ} \mathrm{C}$ olduğu dönemde görülmüsstür. Kapalı havalarda, rüzgarın şiddetli olduğu zaman diliminde ve geceleri, zararlının aktif olmadığı görülmüştür. $\mathrm{Bu}$ tarihte çalışmanın yapıldığı badem bahçesinde sadece erkek anaç olarak kullanılan bademlerde çiçek açıldığı gözlenmiştir.
Sayımlar esnasında, tuzaklarda faydalı böceklerinde olduğu gözlenmiştir. Bu böceklerden bazıları; Bal arısı (Aphis mellifera), Uğur böceği (Coccinella septempunctata) ve az sayida Syrphidae familyasına ait bazı bireylerdir. Yapılan gözlemlerde zararlının meyve döneminde de bulunmasına karşın meyvede herhangi bir zarar oluş̧urduğuna rastlanmamıştır.

\section{Kontrol Tuzak İslemi}

Tuzaklarda kullanılan feromon kapsülünün etkisinin tuzaklara yönelen zararlı üzerindeki etkisini araştırmak amacıyla yapılan kontrol tuzak işlemi verileri (Çizelge 2, Çizelge 3, Çizelge 4)'te verilmiştir. 
Çizelge 2. Eşeysel çekici feromon kapsülünün huni tipi tuzak üzerindeki etkisi

\begin{tabular}{|c|c|c|c|}
\hline \multicolumn{3}{|c|}{ Huni Tipi tuzak } \\
\hline Tarih & A & B & C \\
\hline 22.04 .2015 & 8 & 411 & 45,66 \\
\hline 28.04 .2015 & 12 & 315 & 35 \\
\hline 03.05 .2015 & 0 & 53 & 5,88 \\
\hline 09.05 .2015 & 0 & 11 & 1,22 \\
\hline 14.05 .2015 & 0 & 3 & 0,33 \\
\hline
\end{tabular}

*A: Eşeysel çekici feromon kapsül kullanılmayarak elde edilen 9 tuzaktaki $E$. hirta sayısı, B: Eşeysel çekici feromon kapsül kullanılarak elde edilen 9 tuzaktaki $E$. hirta sayısı, C: Eşeysel çekici feromon kapsül kullanılarak elde edilen 9 tuzaktaki tuzak başına düşen ortalama $E$. hirta sayıs1

Çizelge 3. Eşeysel çekici feromon kapsülünün leğen tipi tuzak üzerindeki etkisi

\begin{tabular}{|c|c|c|c|}
\hline \multicolumn{3}{|c|}{ Leğen Tipi tuzak } & C \\
\hline Tarih & A & 304 & 33,77 \\
\hline 22.04 .2015 & 21 & 284 & 31,55 \\
\hline 28.04 .2015 & 34 & 36 & 4 \\
\hline 03.05 .2015 & 5 & 7 & 0,77 \\
\hline 09.05 .2015 & 0 & 1 & 0,11 \\
\hline 14.05 .2015 & 0 & 0,1 & B \\
\hline
\end{tabular}

*A: Eşeysel çekici feromon kapsül kullanılmayarak elde edilen 9 tuzaktaki E. hirta sayısı, B: Eşeysel çekici feromon kapsül kullanılarak elde edilen 9 tuzaktaki E. hirta sayısı, C: Eşeysel çekici feromon kapsül kullanılarak elde edilen 9 tuzaktaki tuzak başına düşen ortalama E. hirta sayis1

Çizelge 4. Eşeysel çekici feromon kapsülünün kova tipi tuzak üzerindeki etkisi

\begin{tabular}{|c|c|c|c|}
\hline \multicolumn{3}{|c|}{ Kova Tipi tuzak } \\
\hline Tarih & A & B & C \\
\hline 22.04 .2015 & 0 & 36 & 4 \\
\hline 28.04 .2015 & 0 & 20 & 2,22 \\
\hline 03.05 .2015 & 0 & 3 & 0,33 \\
\hline 09.05 .2015 & 0 & 0 & 0 \\
\hline 14.05 .2015 & 0 & 0 & 0 \\
\hline
\end{tabular}

*A: Eşeysel çekici feromon kapsül kullanılmayarak elde edilen 9 tuzaktaki $E$. hirta sayısı, B: Eşeysel çekici feromon kapsül kullanılarak elde edilen 9 tuzaktaki E. hirta sayısı, C: Eşeysel çekici feromon kapsül kullanılarak elde edilen 9 tuzaktaki tuzak başına düşen $E$. hirta sayısı

(Not: Plaka tipi yapışkan tuzağa zararlının yönelmemesi sebebi ile bu tuzak tipi için kontrol tuzak işlemi yapılmadı. Kontrol tuzak işlemi 8. sayımdan başlayarak 12. sayıma kadar olan sayımlarda uygulandı.)

Verilen çizelgelere göre; feromon kapsülün etkisi en fazla huni ve leğen tipi tuzakta görülmüştür. Kova tipi tuzak için feromon etkisi, huni ve leğen tipi tuzağa göre oldukça düşük seviyede kaldığı tespit edilmiştir. Feromon kapsüle yönelen Baklazınnı bireylerinin bir süre feromon kapsül üzerinde gezindikten sonra tuzaklara giriş yaptıkları gözlenmiştir. Çok sayıda Baklazınnı feromon kapsül üzerinde gezinirken gözlemlenmiştir.

\section{SONUCLAR}

Yapılan bu çalışmaya göre Bakla zınnı için kullanılabilecek en etkili tuzak tipleri; huni tipi tuzak ve leğen tipi tuzaktır. Tuzaklarda toplam olarak 8.762 adet Bakla zınnı sayımı yapılmıștır. En fazla Bakla zınnı, huni tipi tuzakta; 5.686 adet olarak sayılmıştır. $\mathrm{Bu}$ tuzağı leğen tipi tuzak; 2.738 adet Bakla zınnı ve kova tipi tuzak; 338 adet Baklazınnı olarak takip etmiştir. Plaka tipi yapışkan tuzağa ise hiç Baklazınnı yönelmemiştir. Sağdaş (2010), Afyonkarahisar ili Sultandağ 1 ilçesinde kiraz ve elma ağaçlarında yaptığ 1 bir çalışmada genç yaştaki ağaçların çiçeklenme dönemlerinde, altında içi su dolu olan mavi renkli huni ile birlikte cezbedici maddenin kullanılmasının, bu dönemlerde ilaçlama yapılamayan Zararlının kontrol altına alınmasında etkili bir biyoteknik yöntem olduğunu bildirmektedir. Yaptığımız bu çalışmada, leğen tipi tuzak ve kova tipi tuzak için eşeysel çekici feromon kapsülün etkinliği huni tipi tuzağa oranla daha düşük seviyelerde kaldığını belirlenmiştir. Ayrıca Schmera ve ark., (2004), zararlısının mavi renge doğru güçlü bir yönelme isteği olduğunu bildirmiștir. Buna paralel olarak aynı durum çalışmamızda kullandığımız mavi renkli tuzaklarda da gözlemlenmiştir.

Uysal (2011), Isparta ili Yalvaç ilçesinde erik ve kayısı ağaçlarında yaptığı bir çalışmada genç yaştaki ağaçların çiçeklenme dönemlerinde, altında içi su dolu olan mavi renkli huni ile birlikte cezbedici maddenin kullanılmasının bu zararlıyı yakalamada etkili olduğunu ve erik ağaçlarında kayısı ağaçlarına göre daha fazla bireyin yakalandığını bildirmiştir. Bizim yaptığımız çalışmadaki uygulamalarda benzer şekilde yapılmıştır. 
Ancak farklı olarak badem bahçesinde yapılmıştır. Aydın (2011), Prunus spp. üzerinde yaptığı bir çalışmada çiçeklenme öncesi ve sonrası dönemlerde beyaz renkli, çiçeklenme sırasında ise mavi renkli tuzaklarda daha fazla E. hirta yakalandığını bildirmektedir. Yaşar (2013), Isparta ilinde farklı mavi renkli huni tuzaklarının kiraz ağaçları çiçeklerinde beslenen Baklazınnı [Epicometis hirta (Poda) (Coleoptera: Scarabaeidae)]'nın yakalanması üzerine etkisini araştırmak amacı ile yaptığı çalışmada, 794 birey ile en fazla ergin "light steel blue1" olarak isimlendirilen ve hexadecimal kodu \#C6DEFF (rgb decimal $\operatorname{kod}(198,222,255)$ ) olan huni tuzaklarda yakalandığını ve bunu 451 birey ile "light blue" olarak isimlendirilen ve hexadecimal kodu \#ADDFFF (rgb decimal code $(173,223,255)$ ) olan tuzaklarda yakalandığını bildirmiştir. $\mathrm{Bu}$ da bizim çalışmamızda elde ettiğimiz verileri desteklemektedir.

Denemenin yapıldığı alanda zararlı Epicometis hirta'nın sadece çiçek organına zarar verdiği tespit edilmiştir. Çiçeklerin meyveye dönüşmesinden sonraki süreçte zararlının hala var olmasına karşın, meyvede herhangi bir zararına rastlanmamıștır. Zararlının meyve dönemini genellikle yabancı otlar üzerinde geçirdiği tespit edilmiştir. Ayrıca çiçek döneminin bitmesi ile zararlının populasyon yoğunluğu hızlı bir şekilde düşmeye başladığı da yapılan sayımlar sonucu görülmüştür. Zararlının bir kısmı, çiçek döneminin bitmesi ile ovaya uçuş yaptığı tespit edilmiştir. Bakla zınnı (Epicometis hirta) en fazla huni tipi tuzağa yönelmiştir. Feromon etkisi en fazla bu tuzak tipinde görülmüştür. Kontrol tuzaklarda bu durum, net bir şekilde ortaya koyulmuştur. Eşeysel çekici feromon kapsülün asılmadığı kontrol tuzaklardaki Baklazınnı sayısı, eşeysel çekici feromon kapsülün asılı olduğu tuzaklardaki Baklazınnı sayısına oranla oldukça düşük sayıda olduğu görülmüştür. Eşeysel çekici feromon kapsülün etkisinin en az kova tipi tuzakta olduğu görülmüştür (Çizelge 2, 3, 4).

Yapılan gözlemler sonucu Bakla zınnının tuzaklara yönelmesi öncelikle eşeysel çekici feromon kapsüle yönelimi şeklindedir. Sicaklık ve nemin, zararlının popülasyon yoğunluğuna etkisi, belirlenmiştir. Elde edilen sonuçlara göre; zararlı, bitkinin fenolojik olarak zarar yaptığı çiçek döneminde iken; günlük sicaklık ortalamasının $13-15{ }^{\circ} \mathrm{C}$ sıcaklık ve günlük ortalamasının \% 40-60 nem aralığında olduğu zaman dilimlerinde popülasyon yoğunluğunun maksimum düzeye ulaştığı görülmektedir.

Yapılan bu çalışma ile Bakla zınnı (Epicometis hirta) için ilaçlı mücadeleye gerek olmadığı, tuzak yönteminin bu zararlı ile mücadelede çok daha etkin olacağı ortaya konulmuştur. Zararlının çiçek döneminde zarar yapması ve o dönemde yapılacak olası bir ilaçlamanın, tozlaşmada etkin bir role sahip Bal arısı (Aphis mellifera)' ların olumsuz etkilenmesine yol açacağından, ayrıca tuzakla mücadele yönteminin ilaçlı mücadeleye göre hem daha etkili hem de çevre sağlı̆̆ için daha uygun olması, tuzakla mücadele yönteminin önemini ortaya koymaktadır.

\section{TESEKKÜR}

2015/1-23 YLS numaralı projemin yapılmasında maddi kaynaklarını esirgemeyen Kahramanmaraş Sütçü İmam Üniversitesi Bilimsel Araştırma Projeleri birimine teşekkürlerimi sunarım.

\section{KAYNAKLAR}

Atlı, H., Karadağ, S., Sarpkaya, K., Konukoğlu, F., Bozkurt, H. 2011. Badem Yetiştiriciliği El Kitabı. Gaziantep, 15 s.

Aydın, G. 2011. Plant Phenology-Related Shifts in Color Preferences of Epicometis (Tropinota) hirta (Coleoptera: Scarabaeidae: Cetoniinae) Adults Key to Effective Population Monitoring and Suppression. Florida Entomologist, 94 (4): 832-838.

Bahadıroğlu, C., Akıncı, M., Kalkar, Ö., 2007. Kahramanmaraş Ahır Dağı'nda Cetoniidae ve Buprestidae (Coleoptera) Familyalarına Bağlı Türler ve $\mathrm{Bu}$ Türlerin Yükselti Basamaklarına Göre Dağılımı. KSÜ Fen ve Müh. Der., 10(1):6-12.

Demir, A. 2005. Gazi Üniversitesi Zooloji Müzesindeki Cetoniidae (Coleoptera) Familyası Örneklerinin Değerlendirilmesi. Yüksek Lisans Tezi, Gazi Üniversitesi, Fen Bil. Enst., Ankara, 124 s.

Gezer, B., 2015. Çanakkale İli Meyve Alanlarında Zararlı Baklazınnı (Epicometis (=Tropinota) hirta (Poda) (Coleoptera: Scarabaeidae)'nın Yakalanmasında Farklı Tuzakların Etkisinin Belirlenmesi. Yüksek Lisans Tezi, On Sekiz Mart Üniversitesi, Fen Bil. Enstitüsü, Çanakkale, 57 s.

Hurpin B. 1962. Super-Familledes Scarabaeoideapp 24-204. In: Entomologie Appliquée a l'Agriculture Tome I. Coléoptère. (Ed: A.S.,Balachowsky), Masson et Cie, Paris, 564 pp.

Kutinkova, H., Andreev R. 2004. Integrated pest management in sweetcherry (Prunus aviumL.) orchards in Bulgaria. J. of Fruitand Ornamental Plant Research, 12: 41-47.

Mitko, A.S., Teodora, B.T., Radoslav,A. A. , Vilina, D.P., Vasilina,D.M., Teodora,S.S. , Nikolina, T.M., Petko, M.M., Dimitar, I.V., 2011. Employing floral baited traps for detection and season almonitoring of Tropinota (Epicometis) hirta (Poda) (Coleoptera: Cetoniidae) in Bulgaria. Acta Zoologica Bulgarica, 63 (3): 269-276.

Özbek, H., Güçlü, Ş., Hayat, R., Yıldırım, E. 1998. Meyve, Bağ ve Bazı Süs Bitkileri Zararlıları. Atatürk Üniv. Yay. No:792, Erzurum, 357 s.

Özbek, H. 2008. Türkiye'de 1lıman iklim meyve türlerini ziyaret eden böcek türleri. Uludağ Arıcılık Der., 8: 92-103.

Özçağıran, R., Ünal, A., Özeker, E., İsfendiyaroğlu, M., 2005. Ilıman İklim meyve Türleri. Yumuşak Çekirdekli Meyveler. Cilt II. Ege Üniv. Ziraat Fak. Yay. No: 556. $200 \mathrm{~s}$. 
Rugini, E., Monastr, F., 2003. Temperate Fruits. In S.K. Mitra, D.S. Rathora and T.K. Bose (Eds), Display Printers (P) LTD. India, ISBN 81-9001711-X, Volume II, 344-414.

Sağdaş, A. 2010. Farklı Tuzakların Afyon İli Sultandağ1 İlçesinde Kiraz ve Elmalarda Zarar Yapan Baklazınnı (Epicometis (=Tropinota) hirta (Poda) (Coleoptera: Scarabaeidae)'nın Yakalanması Üzerine Etkisi. SDÜ, Fen Bil. Enst., Y. Lisans Tezi, Isparta, $162 \mathrm{~s}$.

Schmera, D., Toth, M., Subchev, M., Sredkov, I., Szarukan, I., Jermy, T., Szentesi, A. 2004. Importance of visual and chemical cues in the development of an attractant trap for Epicometis (Tropinota) hirta Poda (Coleoptera: Scarabaeidae). Crop Protection, 23 (10): 939-944.
Soylu, A. 2003. Ilıman İklim Meyveleri II. Uludağ Üniv. Ziraat Fak. Ders Notları No:72, Bursa.

Uysal, O. 2011. Farklı Tuzakların Isparta İli Yalvaç İlçesinde Armut ve Eriklerde Zarar Yapan Baklazınnı (Epicometis (=Tropinota) hirta (Poda) (Coleoptera: Scarabaeidae))'nın Yakalanması Üzerine Etkisi. SDÜ, Fen Bil. Enst., Y. Lisans Tezi, Isparta, $166 \mathrm{~s}$.

Yaşar, B., Çeşme, İ., Baydar, M.S., Aysal, İ., Yazır, A.B. 2013. Farklı mavi renkli huni tuzaklarının kiraz ağaçları çiçeklerinde beslenen Bakla zınnı [Epicometis hirta (Poda) (Coleoptera: Scarabaeidae)]'nın yakalanması üzerine etkisi. Türk. Entomol. Bült., 3 (2): 99-105. 